\title{
Pengetahuan Pentingnya Nutrisi Dan Pemeriksaan Hipertensi Gestational Pada Multiple Gestation
}

\author{
Supriyatiningsih'1*, Muhammad Kurniawan², Nicko Rachmanio ${ }^{3}$ \\ 1 Obstetrics and Gynecology Department, Faculty of Medicine and Health Sciences, Universitas Muhammadiyah Yogyakarta, Yogyakarta \\ 55183 Indonesia \\ 2 Microbiology Department, Faculty of Medicine and Health Sciences, Universitas Muhammadiyah Yogyakarta, Yogyakarta 55183 Indonesia \\ 3 Surgery Department, Faculty of Medicine and Health Sciences, Universitas Muhammadiyah Yogyakarta, Yogyakarta 55183 Indonesia \\ Email: supriyatiningsih.wenang@uni-muenster.de \\ DOI: $10.18196 / p p m \cdot 39.123$
}

\begin{abstract}
Abstrak
Pengabdian masyarakat yang berjudul "PKM Pengetahuan Pentingnya Nutrisi Dan Pemeriksaan Hipertensi Gestational Pada Multiple gestation" dilaksanakan pada hari Jumat 28 Agustus 2020 pada pukul 14:00-15:30. Metode yang digunakan melalui seminar online via Zoom Meeting kepada pegawai dan keluarga pegawai RS Asri Medical Center. Materi yang diberikan berupa materi pengetahuan tentang kesehatan perempuan, kehamilan kembar, nutrisi ibu hamil, hipertensi ibu hamil dan penanganannya yang didahului dengan melakukan pretest untuk mengukur pengetahuan responden sebelum diadakan seminar dan posttest di akhir kegiatan setelah mendapatkan perlakuan berupa seminar. Bentuk pretest dan posttest menggunakan kuesioner. Kegiatan ini diikuti oleh 20 orang dengan menggunakan media online Zoom Meeting. Bentuk kegiatan pengabdian disesuaikan dengan situasi yang ada, di mana tidak memungkinkan dilakukannya kegiatan dengan berkumpul atau berkerumun seperti kegiatan pengabdian masyarakat pada umumnya.
\end{abstract}

Selanjutnya hasil pretest dan posttest dihitung menggunakan metode Wilcoxon Signed Rank. Hasil pretest dan posttest kemudian dihitung menggunakan metode Wilcoxon Signed Rank. Hasil posttest menunjukkan adanya peningkatan pengetahun dari hasil pretest sejumlah $(75,0 \%)$ dan hasil posttest sejumlah (100,0\%). Dari hasil tersebut menunjukkan adanya peningkatan sebanyak 25\%. Uji tes didapatkan nilai $(p<0,05)$, sehingga disimpulkan bahwa terdapat perbedaan pengetahuan tentang pentingnya nutrisi dan pemeriksaan hipertensi pada multiple gestation sebelum dan sesudah seminar.

Target Luaran yang diharapkan dalam pengabdian masyarakat ini adalah Publikasi Artikel dalam Jurnal Nasional ISSN (Submited).

Kata kunci: Hipertensi gestational, multiple gestation, nutritions, preeklampsia

\section{Pendahuluan}

Preeklampsia dalam kehamilan merupakan penyebab tertinggi morbiditas dan mortalitas dari maternal dan perinatal (1). Gangguan hipetensi kehamilan terjadi pada kurang lebih $10 \%$ wanita hamil di dunia (2). Salah satu penyebab dari tingginya angka kematian ibu adalah hipertensi saat masa kehamilan. Hipertensi merupakan penyebab AKI kedua setelah pendarahan (30.3\%) dengan angka kejadian sebanyak 27.1\% pada tahun 2018 (3). Beberapa penyebab AKI antara lain adalah infeksi, abortus, embolism, penyebab langsung (9.6\%) seperti komplikasi saat melahirkan dan obstruksi jalan lahir juga terdapat penyebab tidak langsung (27.5\%) yang dapat menyebabkan AKI yang merupakan penyakit yang telah diderita ibu seperti HIV/AIDS(4).

Klasifikasi gangguan hipertensi dibagi menjadi 4 kategori, yaitu: 1) preeklampsiaeklampsia, 2) hipertensi kronik, 3) hipertensi kronik dengan superimposed preeclampsia and 4) gestational hypertention (5). Preeklampsia adalah keadaan di mana terdapat hipertensi dan proteinuria dengan onset baru terjadi lebih dari 20 minggu umur kehamilan. Eklampsia memiliki manifestasi yang lebih parah dari preeklampsia dengan adanya fase konvulsi. Hipertensi kronik terjadi sebelum 20 minggu umur kehamilan. Perbedaan dengan gestational hypertention adalah tidak terdapat proteinuria dan onset tekanan darah tinggi terjadi setelah 20 minggu umur kehamilan (6). Terdapat salah satu atau lebih kondisi lain yang menyertai berikut, yaitu: Proteinuria; Disfunsi organ maternal lain seperti: insufiensi renal (kreatinin $\geq 90 \mathrm{~mol} / \mathrm{L}$ ), gangguan liver (kenaikan transaminase dan/atau nyeri kuadran kanan atas atau nyeri epigastrik), komplikasi neurologik, komplikasi hematologik (trombositopenia, hemolisis, DIC); Disfungsi 
uteroplacental (7). Etiologi hipertensi gestational yang dapat menimbulkan preeklampsia hingga saat ini belum diketahui dengan pasti. Beberapa penelitian menujukkan adanya kemungkinan hubungan dengan invasi abnormal tropoblast, aktivasi sel endotel, faktor genetik, faktor nutrisi dan faktor imunologi (8).

Secara keseluruhan prevalensi gangguan hipertensi pada kehamilan sebanyak $5.2 \%$ hingga $8.2 \%$ dan preeklampsia sebanyak 0.2-9.2\%. Prevalensi Preeklampsia terbanyak di Asia yaitu dapat mencapai 6.7\% dibanding Afrika 2.3\%, Eropa 5.2\% dan Amerika Utara 4\%(9). Insidensi preeklampsia di Indonesia sebanyak 5.3\%. Insiden ini menjadi semakin tinggi jika seorang wanita mengalami hamil ganda atau yang disebut dengan multiple gestation (10). Dari berbagai faktor yang dapat menjadi penyebab adalah nutrisi. Pemenuhan nutrisi ibu penting untuk mengurangi masalah yang dapat terjadi dalam masa kehamilan. Salah satu parameter untuk menilai kecukupan nutrisi ibu dapat dilihat dari pemenuhan nutrisi yang digambarkan melalui risiko Kurang Energi Kronis (KEK) (11). Oleh karena itu tim ingin memberikan pengetahuan terhadap masyarakat mengenai pentingnya nutrisi dan pemeriksaan hipertensi gestational pada kehamilan ganda (multiple gestation) pada masa kehamilan.

\section{Metode Pelaksanaan}

Penelitian ini menggunakan metode eksperimen. Jenis metode eksperimen semu (Quasi experiment) yang digunakan adalah jenis One Group Pretest-Postest. Pada penelitian ini penulis berusaha menyelidiki pengaruh suatu perlakuan yang sengaja ditimbulkan terhadap suatu subjek (12).

PKM ini melibatkan 20 orang yang terdiri atas karyawan dan keluarga karyawan Rumah Sakit Asri Medical Center Yogyakarta.

Metode yang digunakan dalam pelaksanaan kegiatan ini mencakup:

1. Melakukan pretest untuk mengetahui sejauh mana pemahaman pentingnya nutrisi dan pemeriksaan hipertensi pada multiple gestation, melalui pengisian kuesioner sebelum pemberian seminar.

2. Melakukan seminar tentang pentingnya nutrisi dan pemeriksaan hipertensi pada multiple gestation.

3. Setelah seminar online zoom meeting dilakasanakan dilanjutkan dengan posttest untuk mengetahui sejauh mana pemahaman pentingnya nutrisi dan pemeriksaan hipertensi pada multiple gestation, melalui pengisian kuesioner setelah pemberian seminar.

1. Seminar online zoom meeting tentang pengetahuan dan upaya deteksi dini kanker payudara pada usia reproduksi ini terdiri dari materi:

a. Materi 1: Pengertian multiple gestation

b. Materi 2: Nutrisi ibu hamil

c. Materi 3: Pentingnya pemerikasaan hipertensi selama kehamilan

d. Materi 4: Penanganan resiko hipertensi selama kehamilan

e. Materi 5: tips dan trik menjaga kesehatan selama kehamilan

\section{Hasil dan Pembahasan}

\section{Profil Responden}

Profil responden dalam penelitian ini meliputi usia, pekerjaan, dan pendidikan. Adapun hasilnya adalah sebagai berikut: 


\begin{tabular}{clccc}
\hline No. & & Profil & Frekuensi & $\%$ \\
\hline 1. & Umur & & \\
& $\leq 30$ tahun & 15 & 75,0 \\
& $31-40$ tahun & 4 & 20,0 \\
& $>41$ tahun & 1 & 5,0 \\
\cline { 2 - 5 } & Jumlah & Pekerjaan & 20 & 100,0 \\
\hline & Bidan & & \\
& Swasta & 5 & 25,0 \\
& Pegawai Swasta & 5 & 25,0 \\
\cline { 2 - 5 } & Jumlah & Pendidikan & 10 & 50,0 \\
\hline SMA & D3 & 20 & 100,0 \\
\hline & S1 & 1 & 5,0 \\
& S2 & 9 & 45,0 \\
\cline { 2 - 5 } & Jumlah & 7 & 35,0 \\
& & 3 & 15,0 \\
\hline
\end{tabular}

Tabel di atas menunjukkan bahwa sebagian besar responden berumur $\leq 30$ tahun, yaitu 15 responden $(75,0 \%)$, dan paling sedikit berumur $>41$ tahun, yaitu 1 responden $(5,0 \%)$. Berdasarkan pekerjaan, sebagian besar adalah pegawai swasta, yaitu 10 responden $(50,0 \%)$, dan yang bekerja sebagai bidan dan swasta, masing-masing 5 responden $(25,0 \%)$. Berdasarkan pendidikan, sebagian besar responden berpendidikan D3, yaitu 9 responden $(45,0 \%)$, dan paling sedikit berpendidikan SMA, yaitu 1 responden $(5,0 \%)$.

\section{Deskripsi Konsep Kurva Normal}

Data pengetahuan dikategorikan dan ditafsirkan dalam kalimat kualitatif, baik, cukup dan kurang. Adapun teknik yang digunakan untuk melakukan kategori digunakan konsep kurva normal. Apabila untuk tiga kategori, maka rentang yang digunakan adalah sebagai berikut :

$$
\begin{array}{ll}
\mathrm{X} \leq(\mu-1,0 \sigma) & =\text { Kurang } \\
(\mu-1,0 \sigma)<\mathrm{X} \leq(\mu+1,0 \sigma) & =\text { Cukup } \\
(\mu+1,0 \sigma)<\mathrm{X} & =\text { Baik }
\end{array}
$$

Nilai $\sigma$ (standar deviasi teoretis) dihitung dari rentang skor dibagi 6. Adapun nilai $\mu$ (mean teoretis) dihitung dari (rentang skor : 2) + skor minimal(12).

Jumlah item dalam kuesoiner pengetahuan sejumlah 10 item dengan skor 0-2. Berdasarkan hal tersebut, maka skor minimal yang mungkin terjadi adalah $10 \times 0=0$ dan skor maksimal yang mungkin terjadi adalah $10 \times 2=20$, sehingga rentang skor ideal adalah $20-0=20$. Standar deviasi teoretis $(\sigma)$ sebesar $(20): 6=3,33$ dan mean teoretis $(\mu)=(20: 2)+0=10$.

Berdasarkan standar deviasi teoretis dan mean teoretis, kemudian dapat dideskripsikan kategori pengetahuan yaitu:

Kurang $: \leq 6$ 
Cukup : $7-13$

Baik $:>13$

\section{Deskripsi Pengetahuan tentang Multiple Gestation Sebelum Seminar}

Pengetahuan tentang multiple gestation sebelum seminar, dapat dideskripsikan sebagai berikut:

Tabel 2. Distribusi Frekuensi Pengetahuan tentang Multiple Gestation Sebelum Seminar

\begin{tabular}{|l|c|c|c|}
\hline \multicolumn{1}{|c|}{ Kategori } & Skor & N & $\%$ \\
\hline Baik & $>13$ & 15 & 75,0 \\
\hline Cukup & $7-13$ & 5 & 25,0 \\
\hline Kurang & $\leq 6$ & 0 & 0,0 \\
\hline \multicolumn{2}{|c|}{ Total } & 20 & 100,0 \\
\hline
\end{tabular}

Tabel 2 menunjukkan bahwa sebelum seminar, sebagian besar responden mempunyai pengetahuan tentang multiple gestation kategori baik, yaitu 15 responden $(75,0 \%)$.

\section{Deskripsi Pengetahuan tentang Multiple gestation Setelah Seminar}

Pengetahuan tentang multiple gestation setelah seminar, dapat dideskripsikan sebagai berikut:

Tabel 3. Distribusi Frekuensi Pengetahuan tentang Multiple gestation Setelah Seminar

\begin{tabular}{|l|c|c|c|}
\hline \multicolumn{1}{|c|}{ Kategori } & Skor & N & $\%$ \\
\hline Baik & $>13$ & 20 & 100,0 \\
\hline Cukup & $7-13$ & 0 & 0,0 \\
\hline Kurang & $\leq 6$ & 0 & 0,0 \\
\hline \multicolumn{2}{|c|}{ Total } & 20 & 100,0 \\
\hline
\end{tabular}

Tabel 2 menunjukkan bahwa setelah seminar, seluruh responden responden $(100,0 \%)$ mempunyai pengetahuan tentang multiple gestation kategori baik.

\section{Uji Beda Pengetahuan tentang Multiple gestation Sebelum dan Sesudah Seminar}

Pengujian uji beda akan dilakukan dengan menggunakan uji t sampel berkorelasi, apabila data penelitian berdistribusi normal. Apabila data penelitian tidak berdistribusi normal, maka pengujian dilakukan dengan menggunakan Wilcoxon Signed Rank Test.

Hasil pengujian normalitas data pengetahuan tentang multiple gestation, dapat dideskripsikan sebagai berikut:

Tabel 4. Rangkuman Hasil Pengujian Normalitas Data

\begin{tabular}{|l|c|c|}
\hline \multicolumn{1}{|c|}{ Statistik } & Sebelum Seminar & Setelah Seminar \\
\hline KS-Z & 0,194 & - \\
\hline $\mathrm{P}$ & 0,048 & - \\
\hline Keterangan & Tidak Berdistribusi Normal & $\begin{array}{c}\text { Tidak Berdistribusi } \\
\text { Normal }\end{array}$ \\
\hline
\end{tabular}

Tabel 4 menunjukkan bahwa data pengetahuan tentang multiple gestation sebelum seminar tidak berdistribusi normalditunjukkan dari nilai $\mathrm{p}<0,05$. Adapun data pengetahuan tentang multiple gestation tidak dapat diuji karena semua datanya bernilai sama.

Berdasarkan data penelitian yang tidak berdistribusi normal, maka digunakan uji statistik nonparametrik, yaitu Wilcoxon Signed Rank Test. Adapun hasilnya adalah sebagai berikut: 
Tabel 5. Uji Wilcoxon Signed Rank Test

\begin{tabular}{|l|c|c|}
\hline \multicolumn{1}{|c|}{$\mathbf{H}_{\mathbf{0}}$} & $\mathbf{p}$ & Keputusan \\
\hline $\begin{array}{l}\text { Tidak ada perbedaan pengetahuan tentang Multiple gestation } \\
\text { sebelum dan sesudah seminar }\end{array}$ & 0,000 & $\mathrm{H}_{0}$ ditolak \\
\hline
\end{tabular}

Tabel 5 menunjukkan bahwa hasil pengujian Wilcoxon Signed Rank Test didapatkan nilai $\mathrm{p}<0,05$, sehingga $\mathrm{H}_{0}$ ditolak, sehingga disimpulkan ada perbedaan pengetahuan tentang multiple gestation sebelum dan sesudah seminar.

\section{Simpulan}

Berdasarkan hasil pengabdian yang telah dilakukan tentang pengetahuan pentingnya nutrisi dan pemeriksaan hipertensi pada multiple gestation di RS Asri Medical Center, maka dapat ditarik simpulan bahwa : hasil posttest menunjukkan adanya peningkatan pengetahun dari hasil pretest sejumlah $(75,0 \%)$ dan hasil posttest sejumlah $(100,0 \%)$. Dari hasil tersebut menunjukkan adanya peningkatan sebanyak $25 \%$. Uji test didapatkan nilai $(\mathrm{p}<0,05)$, sehingga disimpulkan bahwa terdapat perbedaan pengetahuan tentang pentingnya nutrisi dan pemeriksaan hipertensi pada multiple gestation sebelum dan sesudah seminar.

\section{Ucapan Terima Kasih}

Ucapan terima kasih kami tujukan terutama kepada pemberi dana LP3M UMY. Ucapan terima kasih juga kami tujukan kepada segenap karyawan AMC dan keluarganya yang telah mengikuti seminar, serta semua kerabat kerja yang turut membantu dalam terlaksananya program pengabdian ini.

\section{Daftar Pustaka}

Chen Q, Stone P, Ching L-M, Chamley L. A role for interleukin-6 in spreading endothelial cell activation after phagocytosis of necrotic trophoblastic material: implications for the pathogenesis of pre-eclampsia. J Pathol. 2009 Jan;217(1):122-30.

World Health Organization. Global Health Observatory (GHO) data [Internet]. Available from: https://www.who.int/gho/publications/world_health_statistics/2014/en/

Badan Pusat Statistik. Survei Demografi dan Kesehatan Indonesia 2018. 2018.

Say L, Chou D, Gemmill A, Tunçalp Ö, Moller A-B, Daniels J, et al. Global causes of maternal death: a WHO systematic analysis. The Lancet Global Health. 2014 Jun;2(6):e323-33.

Hypertension in Pregnancy: Executive Summary. Obstetrics \& Gynecology. 2013 Nov;122(5):1122-31.

Cheng M-H, Wang P-H. Placentation abnormalities in the pathophysiology of preeclampsia. Expert Review of Molecular Diagnostics. 2009 Jan;9(1):37-49.

Tranquilli AL, Dekker G, Magee L, Roberts J, Sibai BM, Steyn W, et al. The classification, diagnosis and management of the hypertensive disorders of pregnancy: A revised statement from the ISSHP. Pregnancy Hypertension: An International Journal of Women's Cardiovascular Health. 2014 Apr;4(2):97-104.

Cunningham FG, editor. Williams obstetrics. 24th edition. New York: McGraw-Hill Medical; 2014. $1358 \mathrm{p}$.

Umesawa M, Kobashi G. Epidemiology of hypertensive disorders in pregnancy: prevalence, risk factors, predictors and prognosis. Hypertens Res. 2017 Mar;40(3):213-20.

PNPK. Pedoman Nasional Pelayanan Kedokteran Preeklamsia. 2016. 
Achamrah N, Ditisheim A. Nutritional approach to preeclampsia prevention. Current Opinion in Clinical Nutrition \& Metabolic Care. 2018 May;21(3):168-73.

Sugiyono. Metode Penelitian. Bandung: CV Alfa Beta; 2001. 